\title{
Den tradisjonelle \\ forståelsen av autonomi \\ er for snever
}

Med en relasjonell tilnærming tar vi hensyn til rammene og relasjonene rundt pasienten og ser ikke bare vedkommende som et fritt, uavhengig menneske.

\section{Anne Kari Tolo Heggestad}

Professor og forsker

VID vitenskapelige høgskole og Senter for medisinsk etikk, Universitetet i Oslo

Etikk

Relasjonell autonomi

Autonomi

Sykepleien 2021109 (83901) (e-83901)

DOI: 10.4220/Sykepleiens.2021.83901

Autonomi er et sentralt begrep og prinsipp i sykepleieetikken. Det hører også inn som et av de fire etiske prinsippene i helsetjenesten (1). De tre andre prinsippene er rettferdighet, ikke-skade og velgjørenhet. Når vi opplever etiske dilemmaer, er det ofte autonomiprinsippet som kommer i konflikt med et eller flere av de andre prinsippene.

Autonomiprinsippet har fått sterkt fotfeste i

helsetjenesten og er også lovfestet i pasient- og brukerrettighetsloven (2). De fleste kjenner sikkert til kapittel $4 \mathrm{~A}$, som omhandler autonomi og tvang $\mathrm{i}$ somatisk helsetjeneste, eller kapittel 3 om tvungent psykisk helsevern. 
Autonomiprinsippet er både et moralsk og juridisk prinsipp og handler om at pasienten har rett til medbestemmelse, og til å samtykke til helsehjelp.

\section{Autonomi kan forstås på to måter}

I det følgende tar jeg for meg to ulike forståelser av autonomi: den tradisjonelle forstålsen av autonomi og en relasjonell forståelse av autonomi. Og jeg vil hevde at forståelsen vi har av autonomi, kan ha betydning for hvordan vi legger til rette for pasientens medbestemmelse.

Den tradisjonelle forståelsen av autonomi har røtter tilbake til opplysningstiden på 1700-tallet. En av de store filosofene som gjerne forbindes med den tradisjonelle forståelsen av autonomi, er Immanuel Kant (1724-1804).

\section{«Jeg vil hevde at den tradisjonelle forståelsen av autonomi er snever, og at den kan bidra til at vi ikke ser hele mennesket.»}

Ifølge Kant har mennesket verdighet i kraft av sin fornuftsautonomi. Han mente at det er vår evne til å tenke rasjonelt som er grunnlaget for at vi kan ta autonome valg i livene våre (3). Denne forståelsen av autonomi er individsentrert.

Ut fra dette er idealet det frie, uavhengige mennesket med fornuftsevnen i behold. Faren ved å ha et slikt syn er at vi da tenker at mennesker med nedsatt kognitiv funksjon ikke kan være medbestemmende. Og det er en fare for at vi i for stor grad vektlegger det kognitive når vi for eksempel skal vurdere pasientens samtykkekompetanse. 
Jeg vil hevde at den tradisjonelle forståelsen av autonomi er snever, og at den kan bidra til at vi ikke ser hele mennesket. Det kan føre til at vi i større grad heller setter søkelyset på begrensningene enn mulighetene når det gjelder menneskelig utfoldelse. Det kan dessuten bidra til at vi er mer paternalistiske enn nødvendig, for eksempel i møte med mennesker med demens.

\section{En relasjonell autonomi setter pasienten i en kontekst}

Mens den tradisjonelle forståelsen av autonomi vektlegger menneskets fornuft og uavhengighet, tar en relasjonell autonomi utgangspunkt $i$ at vi er avhengige og sårbare som mennesker (4).

\section{«Vi er ikke først og fremst frie og rasjonelle, men like mye relasjonelle mennesker.»}

Vi er ikke først og fremst frie og rasjonelle, men like mye relasjonelle mennesker. Og vi er mer eller mindre avhengige av relasjoner til andre mennesker - som foreldre, familie og venner - fra vi blir født til vi dør.

Ut fra dette perspektivet påvirkes også valgene våre av de relasjonene vi inngår i, og den sosiale sammenhengen vi står i. Ved å ha en relasjonell tilnærming til autonomi henvender vi oss som sykepleiere ikke særskilt til pasientens kognitive evner eller møter pasienten først og fremst som et rasjonelt menneske.

Vi møter pasienten som et relasjonelt menneske som inngår i en kontekst og sammenheng. Det vil også si at ved å ta hensyn til rammene og relasjonene rundt pasienten kan være med på å påvirke pasientens mulighet til å være medbestemmende. 


\section{Tilnærmingen til autonomi har konsekvenser for pasienten}

Hvilken tilnærming vi har til autonomi, vil også ha konsekvenser for hvordan vi går frem når vi for eksempel vurderer pasientens samtykkekompetanse. Med en relasjonell tilnærming kan vi ikke bare vurdere pasientens kognitive evne og forutsetninger for å forstå informasjon, men vi må se samtykkekompetansen i en større sammenheng.

Vi må vurdere hvordan rammene og menneskene rundt pasienten påvirker pasientens forståelse. Det betyr at vi kan bruke rammene og menneskene rundt pasienten til å hjelpe pasienten med å forstå situasjonen.

Det kan helt konkret bety at jeg for eksempel bør unngå å vurdere pasientens beslutningskompetanse dersom pasienten er i ukjente omgivelser og med mennesker som ikke kjenner pasienten. Eller det kan bety at jeg må sørge for at vi har nok tid når vi vurderer pasientens samtykkekompetanse.

\section{Vi må ta pasientens medbestemmelse på alvor}

Vi har både en moralsk og juridisk plikt til å ta pasientens medbestemmelse på alvor. Derfor mener jeg at vi trenger en diskusjon og refleksjon innen sykepleie om hvilken forståelse for autonomi vi vektlegger, og hvordan det igjen kan virke inn på pasientomsorgen.

Og jeg vil argumentere for at vi som sykepleiere i større grad bør legge vekt på en relasjonell forståelse av autonomi fordi jeg tror at en relasjonell tilnærming til autonomi kan bidra til at pasienter i større grad får muligheten til å medvirke og være medbestemmende. 


\section{Referanser}

1. Beauchamp TL, Childress JF. Principles of

biomedical ethics. 8. utg. New York: Oxford University

Press; 2019.

2. Lov 2. juli 1999 nr. 63 om pasient- og

brukerrettigheter (pasient- og brukerrettighetsloven).

Tilgjengelig fra:

https://lovdata.no/dokument/NL/lov/1999-07-02-63

(nedlastet 02.03.2021).

3. Heggestad AKT. Etikk i klinisk sjukepleie. Oslo:

Samlaget; 2018.

4. Mackenzie C, Stoljar N, red. Relational

autonomy: feminist perspectives on autonomy, agency, and the social self. New York: Oxford University Press; 2000. 